\title{
Soybean whole-plant ensiled with chitosan and lactic acid bacteria: Microorganism counts, fermentative profile, and total losses
}

\author{
J. R. Gandra, ${ }^{* 1}$ C. S. Takiya,† T. A. Del Valle,‡ E. R. Oliveira, ${ }^{*}$ R. H. T. B. de Goes, ${ }^{*}$ E. R. S. Gandra, ${ }^{*}$ \\ J. D. O. Batista, ${ }^{*}$ and H. M. C. Araki* \\ *Department of Animal Science, Universidade Federal da Grande Dourados, Rodovia Dourados-Itahum, Dourados, MS, Brazil 79804-970 \\ †Department of Animal Sciences and Industry, Kansas State University, Manhattan 66506 \\ ‡Department of Animal Nutrition and Animal Production, University of Sao Paulo, Pirassununga, Brazil 13635-900
}

\section{ABSTRACT}

Chitosan is a biopolymer derived from chitin deacetylation, present in the exoskeleton of crustaceans and insects. Chitosan has been evaluated as rumen modulator and silage additive due to its antimicrobial properties. The objective of this study was to determine the effects of both chitosan and a bacterial additive on microbiological quality, chemical composition, nutrient in vitro degradation, fermentative profile, and total losses of whole-soybean plant silage (SS) harvested at R6 stage. Four treatments in a factorial arrangement were randomly assigned to 40 experimental minisilos as no additives $(\mathrm{CON}), 8 \mathrm{~g} / \mathrm{t}$ fresh forage of microbial inoculant (INO; Kera SIL, Kera Nutrição Animal, Bento Gonçalves, Brazil); $5 \mathrm{~g} / \mathrm{kg}$ of fresh forage chitosan (CHI); and CHI + INO. Microbial inoculant was composed of Lactobacillus plantarum $\left(4.0 \times 10^{10} \mathrm{cfu} / \mathrm{g}\right)$ and Propionibacterium acidipropionici $\left(2.6 \times 10^{10} \mathrm{cfu} / \mathrm{g}\right)$. The CHI and INO alone increased counts of lactic bacteria and anaerobic bacteria and decreased counts of mold and yeast in SS. The CHI or INO alone increased in vitro degradation of dry matter, crude protein, and neutral detergent fiber, and decreased nonfiber carbohydrate content of SS. Chitosan increased $\mathrm{NH}_{3}-\mathrm{N}$ and lactate concentrations and decreased ethanol concentration in SS. The CHI increased dry matter recovery from SS; INO increased silage aerobic stability. The combination of $\mathrm{CHI}+\mathrm{INO}$ showed the lowest value of gas losses. In general, the combination of CHI and INO had small positive effects on gas losses of SS; however, both CHI or INO alone improved nutrient in vitro degradation and decreased mold and yeast in SS. Chitosan or INO utilization improves SS quality.

Key words: chitin, Lactobacillus plantarum, legume silage, Propionibacterium acidipropionici

Received December 10, 2017.

Accepted April 9, 2018.

${ }^{1}$ Corresponding author: jeffersongandra@ufgd.edu.br

\section{INTRODUCTION}

Soybeans were initially used as a hay or forage crop (Smith and Huyser, 1987), but production has shifted over time toward grain because of an increase in cereal prices. Previously, farmers ensiled soybeans to avoid forage shortage when adverse weather (i.e., early frost) jeopardizes the potential of high-quality grain production (Undersander et al., 2007). Soybeans have also been ensiled mixed with tropical grasses to improve silage composition in terms of protein content (Stella et al., 2016). Currently, cultivars are bred to improve forage or silage production of soybeans (Devine and Hatley, 1998; Sheaffer et al., 2001); these cultivars can replace alfalfa silage without affecting feed efficiency and ECM of cows producing $35 \mathrm{~kg} / \mathrm{d}$ of milk (VargasBello-Pérez et al., 2008).

The soybean plant has low DM content and high contents of protein, oil, and ash that are positively associated with effluent production and buffering capacity. Nevertheless, studies have shown soybeans can be well preserved as silage (Mustafa and Seguin, 2003). Unlike corn, sorghum, or alfalfa silages, little is known in terms of enhancing fermentation profile of whole-plant soybean silage (SS) through additives. Nkosi et al. (2016a) reported an improvement in the aerobic stability and lactic acid content after adding a mixture of lactic acid bacteria (LAB) and fibrolytic enzymes to SS. Recently, researchers demonstrated that SS ensiled with molasses and homofermentative LAB (Lactobacillus plantarum and Pediococcus pentosaceus at application ratio of 4:1 and $\left.10^{6} \mathrm{cfu} / \mathrm{g}\right)$ exhibited higher production of lactic acid and acetic acid, as well as lower $\mathrm{pH}$ and butyric acid production compared with control group ( $\mathrm{Ni}$ et al., 2017). The positive effects of LAB on fermentative profile of different silages (corn, sorghum, and alfalfa) are described elsewhere (Filya, 2003; Filya et al., 2007; Contreras-Govea et al., 2013). However, the application of homofermentative LAB has been positively associated with aerobic spoilage of silages (Weinberg et al., 1993), either due to low production of organic 
acids, which is not enough to inhibit aerobic yeasts and molds (Moon, 1983), or due to utilization of lactic acid by lactate-assimilating yeasts (Wohlt, 1989). To minimize the aerobic spoilage of silages, LAB have been inoculated along with propionic acid bacteria such as Propionibacterium acidipropionici (Filya et al., 2004). Propionic acid bacteria ferment sugars and lactate into acetate and propionate, which can inhibit the growth of yeasts and molds (Moon, 1983).

Chitosan is a biopolymer derived from the deacetylation of chitin, the second most abundant natural polymer that composes the exoskeleton of crustaceans and insects (Senel and McClure, 2004). Chitosan has demonstrated antimicrobial activity against bacteria and fungi, being able to completely inhibit dimorphic fungi proliferation in in vitro studies (Senel and McClure, 2004; Olicón-Hernández et al., 2015). For instance, sugarcane silage-treated chitosan showed longer aerobic stability and higher concentration of lactic acid in comparison with control or compared with sugarcane silage treated a mixture of Lactobacillus buchneri and Bacillus subtilis (Gandra et al., 2016a).

Despite the positive effects of LAB inoculants or chitosan on forage preservation, few studies have evaluated their combination; thus, it is unknown whether chitosan has any detrimental effects on LAB establishment and consequently on SS fermentation. Recently, Del Valle et al. (2018) reported a positive interaction effect between chitosan and inoculant on fermentative losses and DM recovery (DMR) of sugarcane silage. The evidence that chitosan decreases yeasts and molds and increases lactic acid concentration in silage (Gandra et al., 2016a) raises the hypothesis that chitosan could increase the substrate availability (lactic acid) for $P$. acidipropionici fermentation and potentiate its effects on aerobic stability. Therefore, the objective of our study was to evaluate the effects of chitosan and a mixture of $L$. plantarum and $P$. acidipropionici on microorganism counts, chemical composition, fermentative profile, total losses, and aerobic stability of SS.

\section{MATERIALS AND METHODS}

This experiment was carried out between January and April 2016 at the Department of Animal Science of Federal University of Grande Dourados, located at $22^{\circ} 14^{\prime} \mathrm{S}, 54^{\circ} 49^{\prime} \mathrm{W}$ and $450 \mathrm{~m}$ of altitude.

\section{Harvesting, Treatments, and Ensiling}

Soybeans (Glycine max cultivar GMX Cancheiro RR; GMX Genética, Passo Fundo, Brazil) were grown in an experimental field divided in 10 locations within a 4-ha plot until reaching the R6 stage at 105 d (Coffey
Table 1. Chemical composition of whole-plant soybeans before ensiling ( $\mathrm{g} / \mathrm{kg}$ of DM, unless otherwise stated)

\begin{tabular}{lc}
\hline Item & Composition \\
\hline DM, g/kg of fresh material & 342 \\
OM & 902 \\
NDF & 533 \\
ADF & 316 \\
CP & 195 \\
NFC & 121 \\
Ash & 97.9 \\
Lignin & 86.5 \\
Fat & 53.3 \\
NE ${ }_{\mathrm{L}}{ }^{\text {Mcal }} / \mathrm{kg}$ & 1.88 \\
Buffering capacity, mEq/kg of DM & 505 \\
\hline
\end{tabular}

${ }^{1}$ Calculated according to the NRC (2001).

et al., 1995). Approximately $100 \mathrm{~kg}$ of soybeans from each location was manually harvested (ground level) and chopped to a theoretical cut of $10 \mathrm{~mm}$ using a stationary cutter. Samples (1,000 g) of chopped soybean plant were assessed for contents of DM (method 950.15), ash (method 942.05), OM (DM - ash), CP (N $\times 6.25$; method 984.13), and ether extract (EE; method 920.39) according to AOAC International (2000; Table 1). Nonfiber carbohydrate was calculated as $\mathrm{NFC}=$ $1,000-(\mathrm{NDF}+\mathrm{CP}+\mathrm{EE}+$ ash $)$, all values expressed as grams per kilogram of DM. Neutral detergent fiber (without sodium sulfite), ADF, and lignin (sulfuric acid method) were determined according to Van Soest et al. (1991). Net energy of lactation was estimated according to NRC (2001). Silage buffering capacity was analyzed according to Playne and McDonald (1966).

Four treatments in a factorial arrangement were randomly assigned to 40 experimental silos (plastic buckets, $30 \mathrm{~cm}$ in height, and $30 \mathrm{~cm}$ in diameter) equipped with Bunsen valves. Two kilograms of sand was placed in the bottom of the buckets and covered with a nylon mesh screen $(500 \mu \mathrm{m})$ to drain effluents. Inoculant and chitosan were applied individually on the forage assigned for each bucket to generate true replications. Forage was added to the buckets at a compaction rate of $650 \mathrm{~kg} / \mathrm{m}^{3}$ and silos were sealed, weighed, and stored at room temperature $\left(25.3 \pm 1.8^{\circ} \mathrm{C}\right.$; mean $\left.\pm \mathrm{SD}\right)$ for 100 d. Treatments consisted of no additives (control; CON), $8 \mathrm{~g} / \mathrm{t}$ of fresh forage microbial inoculant (INO; Kera SIL grão úmido, Kera Nutrição Animal, Bento Gonçalves, Brazil); $5 \mathrm{~g} / \mathrm{kg}$ of fresh forage chitosan $(\mathbf{C H I})$, and CHI + INO. Microbial inoculant was composed of L. plantarum $\left(4.0 \times 10^{10} \mathrm{cfu} / \mathrm{g}\right)$ and $P$. acidipropionici $\left(2.6 \times 10^{10} \mathrm{cfu} / \mathrm{g}\right)$. Microbial inoculant was diluted in water $(2 \mathrm{~g} / \mathrm{L})$ and sprayed on the forage. According to manufacturer's information (http://www .kerabrasil.com.br/laminas/Kerasil_Grao_Umido.pdf), CHI presented the following technical specifications: apparent density of $0.64 \mathrm{~g} / \mathrm{mL}, 2.0 \%$ of ash, 7.0 to 
$9.0 \mathrm{pH}$, viscosity $<200 \mathrm{cPs}$, and deacetylation level of 95\% (Polymar Indústria e Cia. Imp. And Exp. LTDA, Fortaleza, Brazil). Chitosan was top-dressed and hand mixed with fresh forage before forage was added into the silos. All silos received the same volume of water and cane molasses (40 g/ $\mathrm{kg}$ of fresh forage).

\section{Microbiological Quality}

Samples (100 g) from the intermediate layer (between 10 to $20 \mathrm{~cm}$ of silo height) within each silo were collected at the silo opening (d 100) for microbiological profile determination. Ten grams from samples was diluted in sterilized sodium chloride solution $(0.9 \%, 90 \mathrm{~mL})$ and a serial dilution was performed. Microorganism counts were carried out in triplicate through decimal dilution series in plates with De Man, Rogosa, Sharpe agar for LAB (Briceño and Martínez, 1995), nutrient agar for aerobic and anaerobic bacteria ( $48 \mathrm{~h}$ of incubation at $\left.30^{\circ} \mathrm{C}\right)$, and potato dextrose agar $(120 \mathrm{~h}$ of incubation at $\left.26^{\circ} \mathrm{C}\right)$ for mold and yeast as described by Rabie et al. (1997). The absolute values were obtained as colonyforming units and then log-transformed.

\section{Chemical Composition and In Vitro Degradation}

Forage samples $(500 \mathrm{~g})$ from each experimental silo were collected to assess DM, OM, NFC, CP, EE, NDF, $\mathrm{ADF}$, lignin, ash, and $\mathrm{NE}_{\mathrm{L}}$, as previously described. Dry matter, CP, and NDF in vitro digestibility were determined using filter bags and artificial rumen incubator (TE-150, Tecnal, Piracicaba, Brazil) according to Tilley and Terry (1963) and adapted by Holden (1999). Briefly, filter bags with samples were incubated for 48 $\mathrm{h}$ at $39^{\circ} \mathrm{C}$ in a buffer-inoculum solution $(1,600 \mathrm{~mL}$ of buffer solution and $400 \mathrm{~mL}$ of rumen inoculum). Jars containing the buffer-inoculum solution were purged with $\mathrm{CO}_{2}$ and lids had gas relief valves. After the incubation period, the buffer-inoculum was drained from the jars and the filter bags were gently squeezed against the sides of the jar to remove the gas trapped in the inflated bags. Afterward, bags were rinsed in jars with 3 changes of warm tap water.

\section{Fermentative Profile}

Silage juice was extracted from forage samples using a hydraulic press and $\mathrm{pH}$ was measured using a digital potentiometer (MB-10, Marte, Santa Rita do Sapucaí, Brazil). Silage juice aliquots $(2 \mathrm{~mL})$ were mixed with 1 $\mathrm{mL}$ of sulfuric acid $(1 N)$ for determination of ammonia nitrogen concentration through colorimetric method described by Foldager (1977).
Volatile fatty acids, ethanol, and lactic acid concentrations in silage juice were determined at the Department of Applied Chemistry of Federal University of São Carlos (Araras, Brazil) according to the methods described by Rodrigues et al. (2012). Briefly, aliquots $(1 \mathrm{~mL})$ of silage juice were mixed with formic acid $(0.2$ $\mathrm{mL}$ ) in amber glass bottles and frozen until analysis. Volatile fatty acids and ethanol concentrations were determined in a gas chromatograph (Focus GC, Thermo Fisher Scientific Inc., Waltham, MA) equipped with an automatic sample injector (model AS-3000, Thermo Fisher Scientific Inc.), a glass column $(2.0 \mathrm{~m} \times 0.5$ cm 80/120 Carbopack B-DA/4\% Carbowax 20M phase; Sigma-Aldrich, St. Louis, MO), and a flame ionization detector set at $270^{\circ} \mathrm{C}$. The chromatograph oven and injector temperatures were set to $190^{\circ} \mathrm{C}$ and $220^{\circ} \mathrm{C}$, respectively. Hydrogen was used as the carrier gas flowing at $30 \mathrm{~mL} / \mathrm{min}$. The lactic acid concentration was measured by HPLC (LC-10ADVP Shimadzu HPLC system, Shimadzu Inc., Kyoto, Japan) according to Ding et al. (1995).

\section{Total Losses and Aerobic Stability}

After $100 \mathrm{~d}$ of storage, experimental silos were weighed to determine gas losses. Effluent losses were calculated based on difference between the weight of silo assembly (plastic bucket, nylon screen, and sand layer) before storage and weight of silo assembly (plastic bucket, nylon screen, and sand layer containing silage effluent) after $100 \mathrm{~d}$.

Gas losses were determined through the equation

$$
\mathrm{GL}=\frac{\mathrm{SWE}-\mathrm{SWO}}{\mathrm{DME} \times 100}
$$

where GL is gas losses (\% DM), SWE is the silo weight at ensiling $(\mathrm{kg})$, SWO is the silo weight at opening $(\mathrm{kg})$, and DME is the forage ensiled on DM basis.

Effluent losses were calculated as

$$
\mathrm{EL}=\frac{\mathrm{SAA}-\mathrm{SAB}}{\mathrm{FE} \times 1,000}
$$

where EL is the effluent production ( $\mathrm{kg}$ of effluent produced/t of forage ensiled), SAA is the weight of silo assembly after the opening $(\mathrm{kg}), \mathrm{SAB}$ is the weight of silo assembly before ensiling, and FE is the amount of forage ensiled $(\mathrm{kg})$.

Dry matter recovery was estimated as

$$
\mathrm{DMR}=\frac{\mathrm{FDM}}{\mathrm{IDM}} \times 100
$$


where FDM is the forage DM after the silos opening $(\mathrm{kg})$ and IDM is the forage DM before the ensiling $(\mathrm{kg})$.

Aerobic stability was considered as the period (h) in which SS temperature remained less than $1^{\circ} \mathrm{C}$ above the room temperature (Driehuis et al., 2001). Silage was removed and silos were weighted to determine effluent losses. During the 6-d period of aerobic stability evaluation, silos were maintained at room temperature (26.3 \pm 2.21 , mean $\pm \mathrm{SD}$ ), and temperature of SS was measured every $8 \mathrm{~h}$ after oxygen exposure using an infrared thermometer (MS6530, Wiltronics Research Pty. Ltd., Victoria, Australia). In addition, samples (200 g) from minisilos of each treatment were collected every $24 \mathrm{~h}$ to determine $\mathrm{DM}$ and $\mathrm{pH}$ after silo oxygen exposure (Kung et al., 1984).

\section{Statistical Analysis}

Data were analyzed using the PROC MIXED of SAS 9.3. (SAS Inst. Inc., Cary, NC), according to the statistical model

$$
Y_{i j k}=\mu+C_{i}+I_{j}+C \times I_{i j}+e_{i j k},
$$

with $e_{i j k} \approx N\left(0, \sigma_{e}^{2}\right)$, where $Y_{i j k}$ is the value of dependent variable, $\mu$ is the overall mean, $\mathrm{C}_{i}$ is the fixed effect of chitosan $(i=1,2), I_{j}$ is the fixed effect of microbial inoculant $(j=1,2), C \times I_{i j}$ is an interaction term, $e_{i j k}$ is the residual error, and $N$ stands for Gaussian distribution, and $\sigma_{e}^{2}$ is the variance associated with silos. Degrees of freedom were corrected by Kenward and Roger (1997) method. When the interaction term was declared significant, dismemberment study was performed using Fisher's protected least significant different means test.

Silage $\mathrm{pH}$ and DM content after aerobic exposure were analyzed as repeated measures, according the following statistical model

$$
\begin{aligned}
Y_{i j k l}=\mu & +C_{i}+I_{j}+C \times I_{i j}+\omega_{k: i j}+T_{l}+T \times C_{l i} \\
& +T \times I_{l j}+T \times C \times I_{l i j}+e_{i j k l},
\end{aligned}
$$

with $\omega_{i j k} \approx N\left(0, \sigma_{\omega}^{2}\right)$ and $e_{i j k l} \approx \operatorname{MVN}(0, R)$, where $Y_{i j k l}$ is the value of dependent variable, $\mu$ is the overall mean, $C_{i}$ is the fixed effect of chitosan $(i=1,2), I_{j}$ is the fixed effect of microbial inoculant $(j=1,2), T_{l}$ is the fixed effect of time (days, $l=1$ to 5 ), $\omega_{k: i j}$ is the random effect of silo $k$ within $i$ th level of chitosan and $j$ th level of inoculant ( $k=1$ to 40$), C \times I_{i j}, T \times C_{l i}, T \times I_{l j}$, and $T \times$ $C \times I_{l i j}$ are interaction terms, $e_{i j k l}$ is the residual error, $N$ stands Gaussian distribution, $\sigma_{\omega}^{2}$ is the variance associated with silos, $M V N$ stands for multivariate normal, and $R$ is the variance-covariance matrix of residuals due to the repeated measurements. Compound symmetry (CS), heterogeneous compound symmetry $(\mathrm{CSH})$, autoregressive (AR), heterogeneous autoregressive (ARH), Toeplitz (TOEP), heterogeneous Toeplitz (TOEPH), factor analytic (FA), Huynh-Felt (HF), unstructured (UN), and variance components (VC) variance and covariance matrixes were evaluated using Bayesian method. Statistical analysis of silage $\mathrm{pH}$ and $\mathrm{DM}$ content were performed using $\mathrm{CSH}$ and $\mathrm{ARH}$ matrices, respectively. Significance level was set at 0.05 .

\section{RESULTS}

\section{Microbiological Quality}

Chitosan increased $(P \leq 0.05)$ overall bacterial counts in SS, including the counts of lactic acid, aerobic, and anaerobic bacteria (Table 2). Inoculant treatment increased $(P \leq 0.05)$ LAB counts. Both CHI and INO individually decreased $(P \leq 0.05)$ mold and yeast counts in SS. A CHI $\times$ INO interaction effect was detected $(P \leq 0.05)$ on total bacteria counts, in which $\mathrm{CHI}$ and

\begin{tabular}{|c|c|c|c|c|c|c|c|c|}
\hline \multirow[b]{2}{*}{ Item } & \multicolumn{4}{|c|}{ Treatment $^{1}$} & \multirow[b]{2}{*}{ SEM } & \multicolumn{3}{|c|}{$P$-value } \\
\hline & $\mathrm{CON}$ & $\mathrm{CHI}$ & INO & $\mathrm{CHI}+\mathrm{INO}$ & & $\mathrm{CHI}$ & INO & $\mathrm{CHI} \times \mathrm{INO}$ \\
\hline Aerobic bacteria & 5.95 & 7.52 & 6.53 & 7.20 & 0.87 & 0.032 & 0.553 & 0.443 \\
\hline Anaerobic bacteria & 6.08 & 7.69 & 6.95 & 7.36 & 1.12 & 0.031 & 0.582 & 0.609 \\
\hline Total bacteria & $6.32^{\mathrm{b}}$ & $7.91^{\mathrm{a}}$ & $7.09^{\mathrm{ab}}$ & $7.59^{\mathrm{a}}$ & 1.09 & 0.029 & 0.543 & 0.032 \\
\hline Mold and yeast & 6.45 & 4.32 & 4.26 & 5.45 & 0.77 & 0.012 & 0.021 & 0.162 \\
\hline
\end{tabular}
CHI+INO treatments showed the highest counts of

Table 2. Microorganism counts $\left(\log _{10}\right)$ of soybean whole-plant silage treated with chitosan and bacterial inoculant

${ }^{\mathrm{a}, \mathrm{b}}$ Values in the same row with a different superscript differ significantly at $P \leq 0.05$ according to Fisher's protected LSD test.

${ }^{1} \mathrm{CON}=$ control, no additives; $\mathrm{CHI}=$ chitosan inclusion of $5 \mathrm{~g} / \mathrm{kg}$ of fresh matter; $\mathrm{INO}=$ bacterial inoculant mixture of Lactobacillus plantarum $\left(\right.$ at $4.0 \times 10^{10} \mathrm{cfu} / \mathrm{g}$ of fresh matter) and Propionibacterium acidipropionici (at $\left.2.6 \times 10^{10} \mathrm{cfu} / \mathrm{g}\right)$; CHI+INO = the combination of chitosan and bacterial inoculant. 
Table 3. Chemical composition and in vitro degradation of soybean whole-plant silage treated with chitosan and bacterial inoculant (g/kg of DM, unless otherwise stated)

\begin{tabular}{|c|c|c|c|c|c|c|c|c|}
\hline \multirow[b]{2}{*}{ Item } & \multicolumn{4}{|c|}{ Treatment $^{1}$} & \multirow[b]{2}{*}{ SEM } & \multicolumn{3}{|c|}{$P$-value } \\
\hline & $\mathrm{CON}$ & $\mathrm{CHI}$ & INO & $\mathrm{CHI}+\mathrm{INO}$ & & CHI & INO & $\mathrm{CHI} \times \mathrm{INO}$ \\
\hline $\mathrm{OM}$ & 937 & 933 & 929 & 932 & 0.16 & 0.940 & 0.199 & 0.377 \\
\hline $\mathrm{NDF}$ & 459 & 547 & 530 & 520 & 1.06 & 0.050 & 0.246 & 0.614 \\
\hline $\mathrm{ADF}$ & 353 & 366 & 320 & 338 & 1.06 & 0.480 & 0.174 & 0.913 \\
\hline $\mathrm{NFC}$ & $200^{\mathrm{a}}$ & $146^{\mathrm{b}}$ & $142^{\mathrm{b}}$ & $162^{\mathrm{ab}}$ & 1.05 & 0.047 & 0.034 & 0.030 \\
\hline Ash & 63.2 & 66.5 & 70.8 & 68.0 & 0.16 & 0.940 & 0.199 & 0.377 \\
\hline Fat & 51.4 & 42.7 & 52.8 & 48.1 & 0.19 & 0.093 & 0.386 & 0.611 \\
\hline $\mathrm{NE}_{\mathrm{L}}{ }^{2}{ }^{2} \mathrm{Mcal} / \mathrm{kg}$ of $\mathrm{DM}$ & $1.70^{\mathrm{b}}$ & $1.81^{\mathrm{a}}$ & $1.82^{\mathrm{a}}$ & $1.77^{\mathrm{ab}}$ & 0.02 & 0.013 & 0.024 & 0.021 \\
\hline \multicolumn{9}{|l|}{ In vitro degradation ${ }^{3}$} \\
\hline DM & $681^{\mathrm{b}}$ & $729^{\mathrm{a}}$ & $725^{\mathrm{a}}$ & $710^{\mathrm{ab}}$ & 1.14 & 0.032 & 0.053 & 0.006 \\
\hline $\mathrm{CP}$ & $701^{\mathrm{b}}$ & $745^{\mathrm{a}}$ & $749^{\mathrm{a}}$ & $730^{\mathrm{ab}}$ & 1.06 & 0.061 & 0.022 & 0.014 \\
\hline
\end{tabular}

${ }^{\mathrm{a}, \mathrm{b}}$ Values in the same row with a different superscript differ significantly at $P \leq 0.05$ according to Fisher's protected LSD test.

${ }^{1} \mathrm{CON}=$ control, no additives; $\mathrm{CHI}=$ chitosan inclusion of $5 \mathrm{~g} / \mathrm{kg}$ of fresh matter; INO = bacterial inoculant mixture of Lactobacillus plantarum $\left(\right.$ at $4.0 \times 10^{10} \mathrm{cfu} / \mathrm{g}$ of fresh matter) and Propionibacterium acidipropionici (at $\left.2.6 \times 10^{10} \mathrm{cfu} / \mathrm{g}\right) ; \mathrm{CHI}+\mathrm{INO}=$ the combination of chitosan and bacterial inoculant.

${ }^{2}$ Calculated according to Weiss et al. (1992) and NRC (2001) at maintenance level.

${ }^{3}$ According to Holden (1999) fermented for $48 \mathrm{~h}$.

total bacteria, INO had intermediate values, and CON presented the lowest values.

\section{Chemical Composition and In Vitro Degradation of DM}

Chitosan increased $(P \leq 0.05)$ NDF content in SS (Table 3 ). A CHI $\times$ INO interaction effect was observed $(P \leq 0.05)$ on $\mathrm{SS}$ contents of $\mathrm{NFC}$ and $\mathrm{NE}_{\mathrm{L}}$, in which the combination of CHI and INO had higher values of $\mathrm{NFC}$ content and lower values of $\mathrm{NE}_{\mathrm{L}}$ in comparison with $\mathrm{CHI}$ and INO alone. Although $\mathrm{CHI}$ and INO alone improved in vitro degradation of $\mathrm{DM}, \mathrm{CP}$, and NDF of
SS, their combination had no effect on silage nutrient degradation in comparison with CON.

\section{Fermentative Profile}

Chitosan increased $(P \leq 0.01) \mathrm{NH}_{3}-\mathrm{N}$ ratio and lactate concentration and decreased $(P=0.05)$ ethanol concentration in SS (Table 4). A CHI $\times$ INO interaction effect $(P \leq 0.05)$ was detected on acetate, propionate, butyrate, isobutyrate, and valerate concentrations in SS. Additives decreased acetate concentration in silage, in which CHI+INO had intermediate values of acetate concentration, and additive treatments alone showed

Table 4. Fermentative profile of soybean whole-plant silage treated with chitosan and bacterial inoculant (g/kg of DM, otherwise stated)

\begin{tabular}{|c|c|c|c|c|c|c|c|c|}
\hline \multirow[b]{2}{*}{ Item } & \multicolumn{4}{|c|}{ Treatment $^{1}$} & \multirow[b]{2}{*}{ SEM } & \multicolumn{3}{|c|}{$P$-value } \\
\hline & $\mathrm{CON}$ & $\mathrm{CHI}$ & INO & $\mathrm{CHI}+\mathrm{INO}$ & & $\mathrm{CHI}$ & INO & $\mathrm{CHI} \times \mathrm{INO}$ \\
\hline $\mathrm{pH}$ & 5.33 & 5.32 & 5.69 & 5.19 & 0.09 & 0.324 & 0.543 & 0.321 \\
\hline $\mathrm{NH}_{3}-\mathrm{N}, \mathrm{g} / \mathrm{kg}$ of total nitrogen & 66.6 & 91.0 & 79.9 & 68.4 & 0.69 & 0.004 & 0.653 & 0.876 \\
\hline Acetate & $0.983^{\mathrm{a}}$ & $0.730^{\mathrm{c}}$ & $0.738^{\mathrm{c}}$ & $0.844^{\mathrm{b}}$ & 0.39 & 0.014 & 0.008 & 0.041 \\
\hline Propionate & $0.103^{\mathrm{b}}$ & $0.120^{\mathrm{a}}$ & $0.096^{\mathrm{b}}$ & $0.025^{\mathrm{c}}$ & 0.14 & 0.004 & 0.126 & 0.005 \\
\hline Butyrate & $2.38^{\mathrm{a}}$ & $2.09^{\mathrm{ab}}$ & $1.81^{\mathrm{b}}$ & $0.79^{\mathrm{c}}$ & 1.68 & 0.321 & 0.321 & 0.006 \\
\hline Isobutyrate & $0.042^{\mathrm{a}}$ & $0.050^{\mathrm{a}}$ & $0.044^{\mathrm{a}}$ & $0.012^{\mathrm{b}}$ & 0.04 & 0.532 & 0.776 & 0.012 \\
\hline Valerate & $0.172^{\mathrm{a}}$ & $0.115^{\mathrm{b}}$ & $0.111^{\mathrm{b}}$ & $0.041^{\mathrm{c}}$ & 0.11 & 0.002 & 0.003 & 0.032 \\
\hline Ethanol & 1.38 & 1.12 & 1.14 & 1.21 & 0.54 & 0.032 & 0.675 & 0.543 \\
\hline Lactate & 5.83 & 7.38 & 5.90 & 6.35 & 0.28 & 0.002 & 0.131 & 0.761 \\
\hline
\end{tabular}

${ }^{\mathrm{a}-\mathrm{c}}$ Values in the same row with a different superscript differ significantly at $P \leq 0.05$ according to Fisher's protected LSD test.

${ }^{1} \mathrm{CON}=$ control, no additives; $\mathrm{CHI}=$ chitosan inclusion of $5 \mathrm{~g} / \mathrm{kg}$ of fresh matter; INO = bacterial inoculant mixture of Lactobacillus plantarum $\left(\right.$ at $4.0 \times 10^{10} \mathrm{cfu} / \mathrm{g}$ of fresh matter) and Propionibacterium acidipropionici (at $\left.2.6 \times 10^{10} \mathrm{cfu} / \mathrm{g}\right)$; CHI+INO = the combination of chitosan and bacterial inoculant. 
Table 5. Total losses and aerobic stability (6-d period) of soybean whole-plant silage treated with chitosan and bacterial inoculant

\begin{tabular}{|c|c|c|c|c|c|c|c|c|}
\hline Item & \multicolumn{4}{|c|}{ Treatment $^{1}$} & SEM & \multicolumn{3}{|c|}{$P$-value } \\
\hline \multicolumn{9}{|l|}{ Losses } \\
\hline Gas, $\mathrm{g} / \mathrm{kg}$ of $\mathrm{DM}$ & 130 & 108 & 129 & 137 & 0.91 & 0.002 & 0.452 & 0.426 \\
\hline Effluent, $\mathrm{kg} / \mathrm{t}$ of fresh material & 63.8 & 56.4 & 66.8 & 47.0 & 3.14 & 0.034 & 0.594 & 0.305 \\
\hline Effluent, $\mathrm{g} / \mathrm{kg}$ of DM & 57.5 & 52.0 & 61.2 & 41.8 & 0.28 & 0.035 & 0.547 & 0.217 \\
\hline \multicolumn{9}{|l|}{ Aerobic stability, ${ }^{\circ} \mathrm{C}$} \\
\hline Accumulated temperature & 311 & 305 & 311 & 299 & 2.28 & 0.065 & 0.483 & 0.506 \\
\hline Maximum & 24.8 & 24.8 & 25.3 & 23.9 & 0.45 & 0.447 & 0.853 & 0.478 \\
\hline Stability & 22.8 & 23.4 & 22.9 & 24.4 & 0.28 & 0.084 & 0.364 & 0.425 \\
\hline Stability, h & 81.0 & 78.0 & 95.0 & 96.0 & 0.35 & 0.543 & 0.005 & 0.641 \\
\hline
\end{tabular}

${ }^{\mathrm{a}, \mathrm{b}}$ Values in the same row with a different superscript differ significantly at $P \leq 0.05$ according to Fisher's protected LSD test.

${ }^{1} \mathrm{CON}=$ control, no additives; $\mathrm{CHI}=$ chitosan inclusion of $5 \mathrm{~g} / \mathrm{kg}$ of fresh matter; $\mathrm{INO}=$ bacterial inoculant mixture of Lactobacillus plantarum (at $4.0 \times 10^{10} \mathrm{cfu} / \mathrm{g}$ of fresh matter) and Propionibacterium acidipropionici (at $2.6 \times 10^{10} \mathrm{cfu} / \mathrm{g}$ ); CHI+INO $=$ the combination of chitosan and bacterial inoculant.

the lowest values of acetate concentration in silage. In general, $\mathrm{CHI}+\mathrm{INO}$ exhibited the lowest values of propionate, butyrate, isobutyrate, and valerate concentrations in silage.

\section{Total Losses and Aerobic Stability}

Chitosan decreased $(P \leq 0.05)$ the losses via gas $(\mathrm{g} /$ $\mathrm{kg}$ of DM) and effluents, and consequently decreased $(P=0.007)$ total losses and increased $(P \leq 0.01) \mathrm{DMR}$ of SS (Table 5). Although INO had no effect on total losses of SS, INO increased $(P \leq 0.01)$ the time in which silage remained stable after oxygen exposure. A $\mathrm{CHI} \times \mathrm{INO}$ interaction effect $(P \leq 0.05)$ was observed on gas losses $(\mathrm{g} / \mathrm{kg}$ of fresh matter) in SS, wherein the lowest value was reported when silage was inoculated with $\mathrm{CHI}+\mathrm{INO}$ and the highest values were found when silage was treated with CHI or INO.

The DM content of SS constantly increased $(P \leq$ 0.01 ) during the 6-d period after silage exposure to oxygen (Figure 1). Soybean silage $\mathrm{pH}$ constantly increased $(P \leq 0.01)$ after $6 \mathrm{~d}$ of oxygen exposure, but the $\mathrm{CHI}+\mathrm{INO}$ treatment maintained $(P \leq 0.01) \mathrm{pH}$ values below 5 until $72 \mathrm{~h}$ after the silos opening whereas other treatments exhibited $\mathrm{pH}$ above 5 after $24 \mathrm{~h}$ of oxygen exposure (Figure 2).

\section{DISCUSSION}

In general, the combination of CHI and INO did not demonstrate positive synergistic effects on microbial quality, fermentation profile, and total losses of SS; thus, our hypothesis was not supported by the results. However, CHI increased LAB counts and lactic acid concentration of SS while decreasing its amounts of mold and yeast. In addition, chitosan-treated silages had the highest values of propionate concentration and DMR. On the other hand, INO only increased silage aerobic stability, with no effects on its fermentative profile. The results above do not support the possible inhibition of INO activity by CHI incorporation in SS, whereas the combination of CHI and INO had minor positive effects (such as higher values of counts of total bacteria and acetate, and lower values of gas losses) on SS quality. Chitosan could exert a negative effect on INO because it has greater bactericidal effects against gram-positive (e.g., L. plantarum and P. acidipropionici) than gram-negative bacteria, and this effect is enhanced at low pH (Senel and McClure, 2004).

The antifungal property of chitosan (Olicón-Hernández et al., 2015) was confirmed in this experiment. Chitosan suppresses sporulation and spore germination of fungi (Hernández-Lauzardo et al., 2008). Mold and yeasts are undesirable microorganisms that cause silage deterioration, and their inhibition is a result of anaerobiosis and acidification (especially by lactic acid) of ensiled forage (Pahlow et al., 2003). Decreasing the amounts of mold and yeast likely increases the nutrient availability for bacterial growth in SS. In addition, lower counts of mold and yeast also increase oxygen concentration in silage favoring the aerobic bacteria growth, including acetic acid bacteria. We expected that the combination of $\mathrm{CHI}$ and INO would exert a positive associative effect in terms of antifungal activity on SS, as chitosan increased lactic acid concentration and decreased the fungi and yeast counts of sugarcane silage (Gandra et al., 2016a) whereas P. acidipropionici (present in INO) can metabolize lactic acid into acetate that inhibits yeasts and molds (Moon, 1983). Indeed, the combination of CHI and INO had higher acetate 


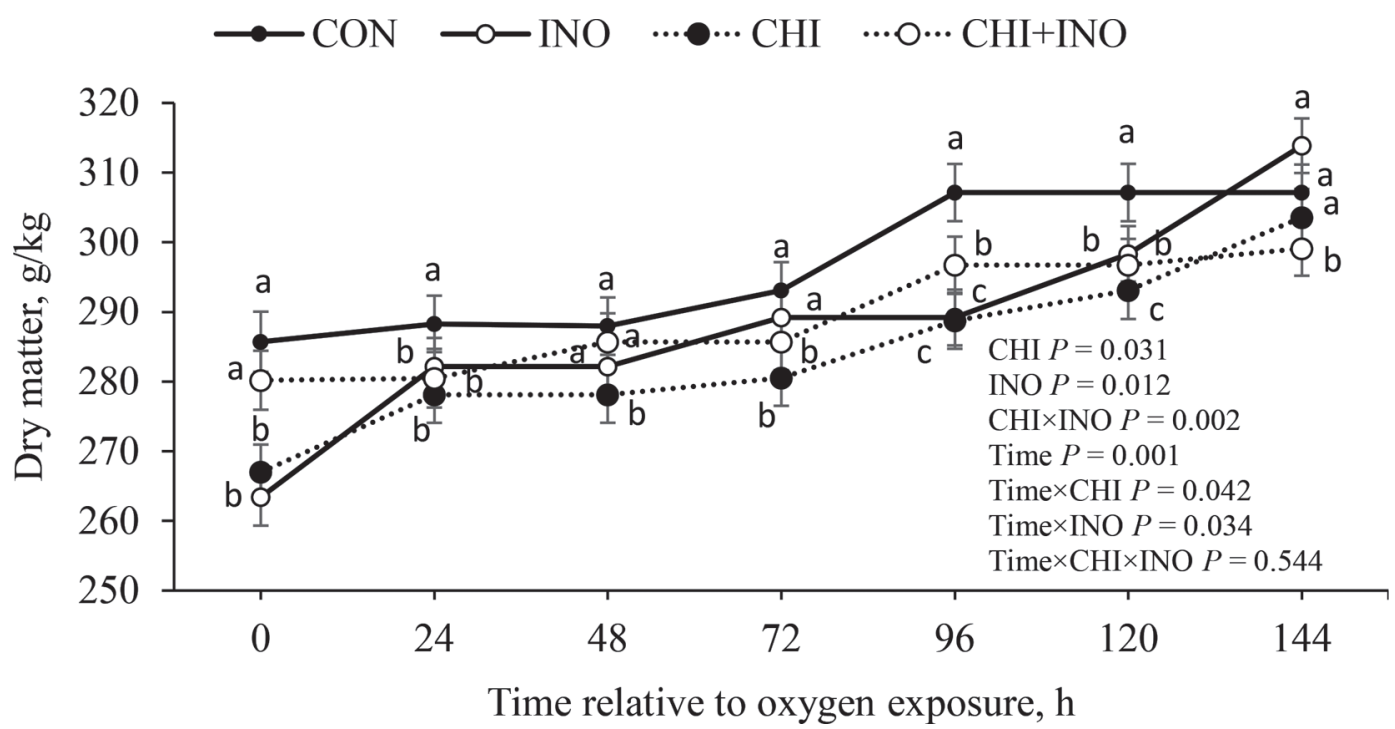

Figure 1. Dry matter content of soybean whole-plant silage treated with chitosan (CHI) or bacterial inoculant (INO) after oxygen exposure. $\mathrm{CON}=$ control, no additives; $\mathrm{CHI}=$ chitosan inclusion of $5 \mathrm{~g} / \mathrm{kg}$ of fresh matter; $\mathrm{INO}=$ bacterial inoculant mixture of Lactobacillus plantarum (at $4.0 \times 10^{10} \mathrm{cfu} / \mathrm{g}$ of fresh matter) and Propionibacterium acidipropionici (at $2.6 \times 10^{10} \mathrm{cfu} / \mathrm{g}$ ); CHI+INO = the combination of chitosan and bacterial inoculant. Pooled SEM $=4.04$. Error bars represent SE. Letters $(\mathrm{a}-\mathrm{c})$ within the same timepoint show that values differed statistically $(P<0.05)$.

concentration but had no effect on mold and yeast counts in comparison with INO alone.

In the current experiment, bacteria showed less sensitivity to the antimicrobial action of chitosan than observed in fungi, agreeing with a review by Kong et al. (2010). It is known that the chitosan bactericidal effect is dependent on $\mathrm{pH}$, with greater activity at $\mathrm{pH}$ values around 4.5 (Senel and McClure, 2004). Although the reasons of increased LAB in chitosan-treated silage are not clear, this effect has been previously reported in sugarcane silage treated with chitosan (Gandra et al., 2016a; Del Valle et al., 2018). Agreeing with the current

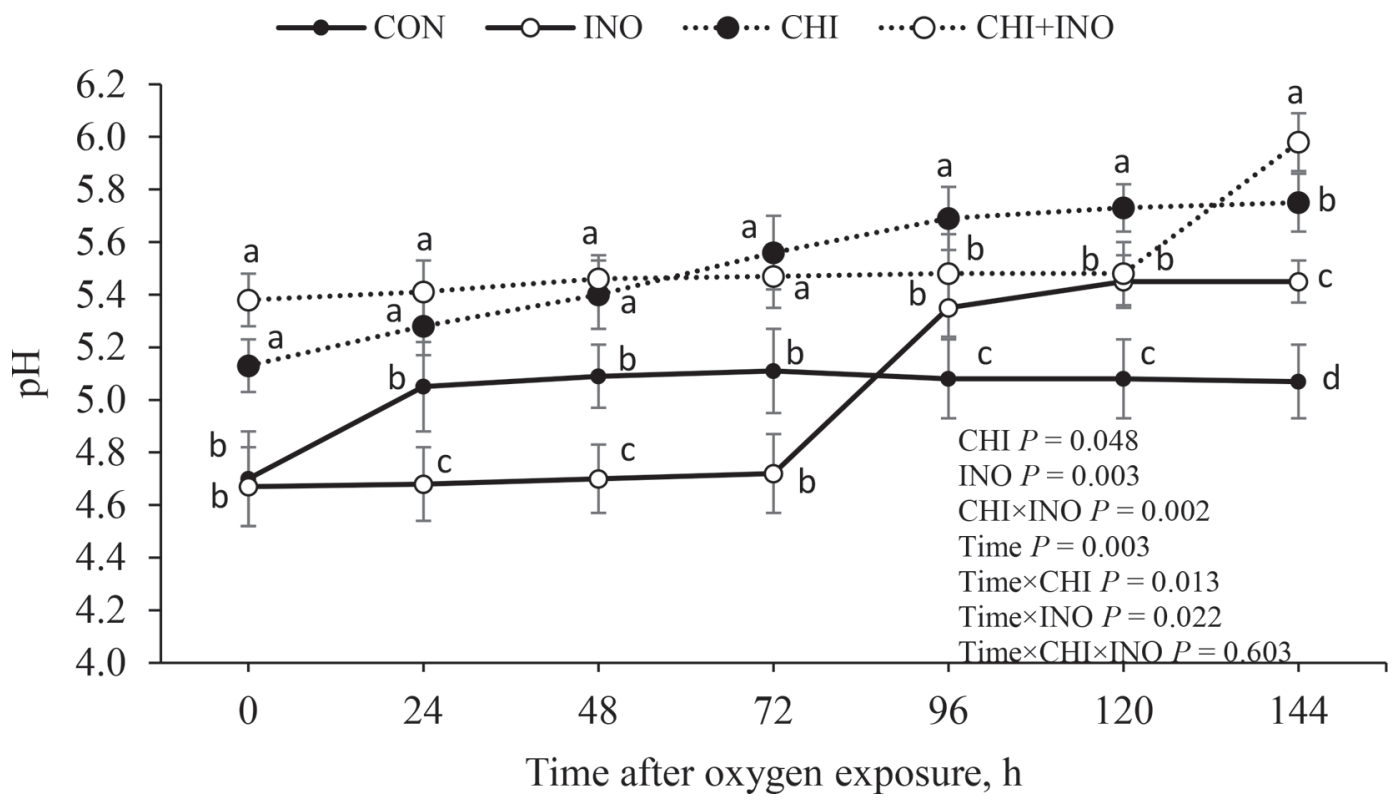

Figure 2. Soybean whole-plant silage $\mathrm{pH}$ treated with chitosan $(\mathrm{CHI})$ or bacterial inoculant (INO) after oxygen exposure. CON $=$ control, no additives; $\mathrm{CHI}=$ chitosan inclusion of $5 \mathrm{~g} / \mathrm{kg}$ of fresh matter; INO = bacterial inoculant mixture of Lactobacillus plantarum (at $4.0 \times 10^{10}$ $\mathrm{cfu} / \mathrm{g}$ of fresh matter) and Propionibacterium acidipropionici (at $\left.2.6 \times 10^{10} \mathrm{cfu} / \mathrm{g}\right) ; \mathrm{CHI}+\mathrm{INO}=$ the combination of chitosan and bacterial inoculant. Pooled SEM $=0.17$. Error bars represent SE. Letters $(\mathrm{a}-\mathrm{d})$ within the same timepoint show that values differed statistically $(P<0.05)$. 
study, Gandra et al. (2016a) observed a reduction in fungi counts and ethanol concentration in sugarcane silage. Finally, it is expected that adding LAB to SS would increase LAB counts. An inoculation rate of $10^{5}$ to $10^{6}$ microorganisms per gram of fresh forage is sufficient for inoculated LAB overwhelm the epiphytic flora and become the predominant population in silage (Kung et al., 2003).

Chitosan and inoculant decreased NFC in SS, whereas $\mathrm{CHI}$ and INO combination had no synergistic effect on silage composition. The highest values of gas losses ( $\mathrm{g} /$ $\mathrm{kg}$ of fresh material) for CHI- and INO-treated silages suggest a greater fermentation of NFC for these treatments, as NFC are the most available carbohydrate source to be fermented in silos. In addition, the lowest values of NFC were related to the highest values of NDF in SS treated with $\mathrm{CHI}$ or INO. Both silage additives increased after $48 \mathrm{~h}$ of in vitro degradation of DM, CP, and NDF, as this effect is related to the greater counts of bacteria in silo in comparison with CON. Improvements in NDF degradation are likely related to LAB production of ferulic acid esterase during the silage storage (Nsereko et al., 2008). Ferulic acid esterase acts on ferulic acid cross-linking of xylans to lignin that limits enzymatic degradation of cell wall (Grabber, 2005). Other authors have reported an increase in NDF degradation when crops were ensiled with LAB (Weinberg et al., 2007; Gandra et al., 2017). Furthermore, chitosan addition to sugarcane silage improved DM (1.5\%) and $\operatorname{NDF}(+4.6 \%)$ in vitro degradation (Gandra et al., 2016a) and chitosan dietary supplementation promoted DM and CP digestibility in dairy heifers, beef steers, and lactating cows (Araújo et al., 2015; Gandra et al., 2016b; Vendramini et al., 2016).

Chitosan increased the $\mathrm{NH}_{3}-\mathrm{N}$ content in SS juice, and this outcome was previously described when adding chitosan to silages (Gandra et al., 2016a). Increased $\mathrm{NH}_{3}-\mathrm{N}$ content in $\mathrm{SS}$ was somewhat expected, as $\mathrm{CP}$ content in chitosan may reach up to $10.8 \%$ and it has been used as a nitrogen source for ruminants (Manni et al., 2010; Fadel El-Seed et al., 2013). Furthermore, glucosamine units $\left(-\mathrm{NH}_{2}\right)$ of chitosan are converted into soluble protonated form $\left(-\mathrm{NH}^{+}{ }_{3}\right)$ when chitosan is present in aqueous acid solution (Goy et al., 2009). In general, the combination of CHI and INO jeopardized fermentation profile of SS in relation to CON, decreasing the production of organic acids critical for silage preservation and animal performance, such as acetate and propionate. To our knowledge, no study has evaluated the combination of CHI and INO on SS fermentation, and the reasons for this antagonistic effect needs elucidation.

In the current experiment, CHI improved DMR of SS due to a reduction in gas and effluent losses. Chitosan has decreased gas and effluent losses and increased DMR in sugarcane silage (Gandra et al., 2016a; Del Valle et al., 2018). Several factors can influence the aerobic deterioration or stability in silages after opening a silo, such as the concentrations of DM, acetic acid, and butyric acid and counts of yeast and molds. A positive association exists between aerobic stability and acetic and butyric acids concentration, whereas DM content and yeast are negatively correlated with aerobic stability and DMR (Ohyama et al., 1980). However, we did not find increases in butyric acid and acetic acid production, and INO decreased the counts of mold and yeast in SS. The combination of LAB and propionic acid bacteria has improved the aerobic stability of silages (Zhang et al., 2015). Furthermore, Nkosi et al. (2016b) reported an increase in the aerobic stability of SS treated with mixture of microbial inoculant (Pediococcus acidilactici and Lactobacillus buchneri) and enzymes (cellulase and hemicellulase).

Greater gas losses ( $\mathrm{g} / \mathrm{kg}$ of natural matter) in the silos treated with $\mathrm{CHI}$ or INO alone were likely related to the microbial count results. According to Oliveira et al. (2018), LAB inoculant improves legume silage fermentation with positive effects on DMR and chemical composition. In the present study, besides increased gas losses (probably associated with increased microbial count) silos treated only with CHI had greater DM in vitro degradation. On the other hand, INO had no effect on DMR but increased microbial counts and nutrient in vitro degradation. Furthermore, CHI and INO had no synergistic effect on previously mentioned parameters.

\section{CONCLUSIONS}

Both CHI and INO alone increased LAB counts and in vitro degradation of nutrients and reduced counts of mold and yeasts of SS. In addition, CHI increased DMR of SS. The combination of CHI and INO had small positive effects of SS fermentation in comparison with ensiling with CHI or INO alone, such as greater acetate concentration and lower butyrate concentration and gas losses; however, these effects were not associated with decreases in mold and yeast counts and improvements in chemical composition of SS. Therefore, incorporating CHI or INO alone to SS is a suitable form to improve SS nutritive and fermentative quality.

\section{ACKNOWLEDGMENTS}

Authors acknowledge Kera Nutrição Animal (Bento Gonçalves, RS, Brazil) for providing the microbial inoculant used in this experiment. 


\section{REFERENCES}

AOAC International. 2000. Official Methods of Analysis. 17th ed. AOAC International, Arlington, VA.

Araújo, A. P. A., B. C. Venturelli, M. C. B. Santos, R. Gardinal, N. R. B. Cònsolo, G. D. Calomeni, J. E. Freitas, R. V. Barletta, J. R. Gandra, P. G. Paiva, and F. P. Rennó. 2015. Chitosan affects total nutrient digestion and ruminal fermentation in Nellore steers. Anim. Feed Sci. Technol. 2016:114-118.

Briceño, A. G., and R. Martínez. 1995. Comparison of methods for the detection and enumeration of lactic acid bacteria. Arch. Latinoam. Nutr. 45:207-212.

Coffey, K. P., G. V. Granade, and J. L. Moyer. 1995. Nutrient content of silages made from whole-plant soybeans. Prof. Anim. Sci. 11:74-80.

Contreras-Govea, F. E., R. E. Muck, G. A. Broderick, and P. J. Weimer. 2013. Lactobacillus plantarum effects on silage fermentation and in vitro microbial yield. Anim. Feed Sci. Technol. 179:61-68.

Del Valle, T. A., T. F. Zenatti, G. Antonio, M. Campana, J. R. Gandra, E. M. C. Zilio, L. F. A. Mattos, and J. G. P. Morais. 2018. Effect of chitosan on the preservation quality of sugarcane silage. Grass Forage Sci. 73:1-9.

Devine, T. E., and E. O. Hatley. 1998. Registration of donegal forage soybean. Crop Sci. 38:1719-1720.

Ding, M. Y., H. Koizumi, and Y. Suzuki. 1995. Comparison of three chromatographic systems for determination of organic acids in wine. Anal. Sci. 2:239-243.

Driehuis, F., W. H. Oude Elferink, and P. G. Van Wiksellar. 2001. Fermentation characteristics and aerobic stability of grass silage inoculant with Lactobacillus buchneri, with or without homofermentative lactic acid bacteria. Grass Forage Sci. 56:330-343.

Fadel El-seed, A. N. M. A., H. E. M. Kamel, J. Sekine, M. Hishinuma, and K. Hamana. 2013. Short Communication: Chitin and chitosan as possible novel nitrogen sources. Can. J. Anim. Sci. 83:161-163.

Filya, I. 2003. The effect of Lactobacillus buchneri and Lactobacillus plantarum on the fermentation, aerobic stability, and ruminal degradability of low dry matter corn and sorghum silages. J. Dairy Sci. 86:3575-3581.

Filya, I., R. E. Muck, and F. E. Contreras-Govea. 2007. Inoculant effects on alfalfa silage: Fermentation products and nutritive value. J. Dairy Sci. 90:5108-5114.

Filya, I., E. Sucu, and A. Karabulut. 2004. The effect of Propionibacterium acidipropionici, with ot without Lactobacillus plantarum, on the fermentation and aerobic stability of wheat, sorghum and maize silages. J. Appl. Microbiol. 97:818-826.

Foldager, J. 1977. Protein requirement and non-protein nitrogen for high producing cow in early lactation. PhD Dissertation. Department of Dairy Science, Michigan State University, East Lansing.

Gandra, J. E., C. S. Takiya, E. R. Oliveira, P. G. Paiva, R. H. T. B. Goes, R. S. Gandra, and H. M. C. Araki. 2016b. Nutrient digestion, microbial protein synthesis, and blood metabolites of Jersey heifers fed chitosan and whole raw soybeans. Rev. Bras. Zootec. 43:130-137.

Gandra, J. R., E. R. Oliveira, E. R. S. Gandra, C. S. Takiya, R. H. T. B. Goes, K. M. P. Oliveira, K. A. Silveira, H. M. C. Araki, N. D. Orbach, and D. N. Vazquez. 2017. Inoculation of Lactobacillus buchneri alone or with Bacillus subtilis and total losses, aerobic stability, and microbiological quality of sunflower silage. J. Appl. Anim. Res. 45:609-614.

Gandra, J. R., E. R. Oliveira, C. S. Takiya, R. H. T. B. Goes, P. G. Paiva, K. M. P. Oliveira, E. R. S. Gandra, N. D. Orbach, and H. M. C. Haraki. 2016a. Chitosan improves the chemical composition, microbiological quality, and aerobic stability of sugarcane silage. Anim. Feed Sci. Technol. 214:44-52.

Goy, R. C., D. Britto, and O. C. G. Assis. 2009. A review of the antimicrobial activity of chitosan. Polímeros 19:241-247.

Grabber, J. H. 2005. How do lignin composition, structure, and crosslinking affect degradability? A review of cell wall model studies. Crop Sci. 45:820-831.

Hernández-Lauzardo, A. N., S. Bautista-Banos, M. G. Velazquez-del Valle, M. G. Mendez Montealvo, M. M. Sanchez-Rivera, and L.
A. Bello-Perez. 2008. Antifungal effects of chitosan with different molecular weights on in vitro development of Rhizopus stolonifer (Ehrenb.:Fr.) Vuill. Carbohydr. Polym. 73:541-547.

Holden, L. A. 1999. Comparison of methods of in vitro dry matter digestibility for ten feeds. J. Dairy Sci. 82:1791-1794.

Kenward, M. G., and J. H. Roger. 1997. Small sample inference for fixed effects from restricted maximum likelihood. Biometrics 53:983-997.

Kong, M., X. G. Chen, K. Xing, and H. J. Park. 2010. Antimicrobial properties and mode of action: A state of the art review. Int. J. Food Microbiol. 144:51-63.

Kung, L., Jr., D. B. Grieve, J. W. Thomas, and J. T. Huber. 1984. Added ammonia or microbial inocula for fermentation and nitrogenous compounds of alfalfa ensiled at various percents of dry matter. J. Dairy Sci. 67:299-306.

Kung, L., Jr., M. R. Stokes, and C. J. Lin. 2003. Silage additives. Pages 305-360 in Silage Science and Technology. D. R. Buxton, R. E. Muck and J. H. Harrison, ed. Am. Soc. Agronomy Inc., Madison, WI.

Manni, L., O. Ghorbel-Bellaaj, K. Jellouli, L. Younes, and M. Nasri. 2010. Extraction and characterization of chitin, chitosan, and protein hydrolysates prepared from shrimp waste by treatment with crude protease from Bacillus cereus SV1. Appl. Biochem. Biotechnol. 162:345-357.

Moon, N. J. 1983. Inhibition of the growth of acid tolerant yeasts by acetate, lactate and propionate and their synergistic mixtures. J. Appl. Bacteriol. 55:454-460.

Mustafa, A. F., and P. Seguin. 2003. Characteristics and in situ degradability of whole crop faba bean, pea, and soybean silages. Can. J. Anim. Sci. 83:793-799.

Ni, K., F. Wang, B. Zhu, J. Yang, G. Zhou, Y. Pan, Y. Tao, and J. Zhong. 2017. Effects of lactic acid bacteria and molasses additives on the microbial community and fermentation quality of soybean silage. Bioresour. Technol. 238:706-715.

Nkosi, B. D., R. Meeske, T. Langa, M. D. Motiang, S. Modiba, T. F. Mutavhatsindi, I. M. M. Malebana, and I. B. Groenewald. 2016b. Effects of bacterial inoculation on the fermentation characteristics and aerobic stability of ensiled whole plant soybeans (Glycine max (L.) Merr.). S. Afr. J. Anim. Sci. 46:129-138.

Nkosi, B. D., R. Meeske, T. Langa, M. D. Motiang, S. Moodiba, N. R. Mkinze, and I. B. Groenewald. 2016a. Effects of ensiling forage soybean (Gkycine $\max (\mathrm{L}$.) Merr.) with or without bacterial inoculats on the fermentation characteristics, aerobic stability and nutrient digestion of silage by Damara rams. Small Rumin. Res. 134:90-96.

NRC. 2001. Nutrient Requirements of Dairy Cattle. 7th ed. Natl. Acad. Press, Washington, DC.

Nsereko, V. L., B. K. Smiley, W. M. Rutherford, A. Spielbauer, K. J. Forrester, H. G. Hettinger, E. K. Harman, and B. R. Harman. 2008. Influence of inoculating forage with lactic acid bacterial strains that produce ferulate esterase on ensilage and ruminal degradation of fiber. Anim. Feed Sci. Technol. 145:122-135.

Ohyama, Y., S. Hara, and S. Masaki. 1980. Analysis of the factors affecting aerobic deterioration of grass silages. Pages 257-261 in Forage conservation in the 80s, BGS Occasional Symposium. C. Thomas, ed. British Grassland Society, Reading, UK.

Olicón-Hernández, D. R., A. N. Hernandez-Lauzardo, J. P. Pardo, A. Pena, M. G. Velazquez-del Valle, and G. Guerra-Sanchez. 2015. Influence of chitosan and its derivatives on cell development and physiology of Ustilago maydis. Int. J. Biol. Macromol. 79:654-660.

Oliveira, M. R., C. C. Jobim, M. Neumann, A. V. I. Bueno, G. F. M. Leão, and J. L. P. Daniel. 2018. Effects of inoculation with homolactic bacteria on the conservation of wheat silage stored in bunker-silos. Ital. J. Anim. Sci. 17:81-86. https://doi.org/10.1080/ 1828051X.2017.1345664.

Pahlow, G., R. E. Muck, F. Driehus, S. J. W. H. Oude Elferink, and S. F. Spoelstra. 2003). Microbiology of ensiling. Pages 31-93 in Silage Science and Technology, v. 42. D. R. Buxton, R. E. Muck, and J. H. Harrison, ed. ASA, CSSA, SSSA, Madison, WI.

Playne, M. J., and P. McDonald. 1966. The buffering constituents of herbage and of silage. J. Sci. Food Agric. 17:264-268. 
Rabie, C. J., A. Lubben, G. J. Marais, and H. Jansen Van Vuuren. 1997. Enumeration of fungi in barley. Int. J. Food Microbiol. 35:117-127.

Rodrigues, P. H. M., R. C. G. Gomes, P. M. Meyer, L. M. O. Borgatii, F. M. J. Franco, and G. L. A. Godoy. 2012. Effects of microbial inoculants and amino acid production by-product on fermentation and chemical composition of sugarcane silage. Rev. Bras. Zootec. 41:1394-1400.

Senel, S., and S. J. McClure. 2004. Potential applications of chitosan in veterinary medicine. Adv. Drug Deliv. Rev. 56:1467-1480.

Sheaffer, C. C., J. H. Orf, T. E. Devine, and J. G. Jewett. 2001. Yield and quality of forage soybean. Agron. J. 93:99-106.

Smith, K. J., and W. Huyser. 1987. World distribution and significance of soybean. Pages 3-22 in Soybeans: Improvement, Production, and Uses. J. R. Wilcox, ed. ASA, Madison, WI.

Stella, L. A., V. Peripolli, E. R. Prates, and J. O. J. Barcellos. 2016. Composição química das silagens de milho e sorgo com inclusão de planta inteira de soja. Bol. Ind. Anim. 73:73-79.

Tilley, J. M. A., and R. A. Terry. 1963. A two-stage technique for the in vitro digestion of forage crops. Grass Forage Sci. 18:104-111.

Undersander, D., K. Jarek, T. Anderson, N. Schneider, and L. Milligan. 2007. A guide to making soybean silage. Forage and Grasslands https://doi.org/10.1094/FG-2007-0119-01-MG.

Van Soest, P. J., J. B. Robertson, and B. A. Lewis. 1991. Methods for dietary fiber, neutral detergent fiber, non-starch polysaccharides in relation to animal nutrition. J. Dairy Sci. 74:3583-3597.
Vargas-Bello-Pérez, E., A. F. Mustafa, and P. Seguin. 2008. Effects of feeding forage soybean silage on milk production, nutrient digestion, and ruminal fermentation of lactating dairy cows. J. Dairy Sci. 91:229-235.

Vendramini, T. H. A., C. S. Takiya, T. H. Silva, F. Zanferari, M. F. Rentas, J. C. Bertoni, C. E. C. Consentini, R. Gardinal, T. S. Acedo, and F. P. Rennó. 2016. Effects of a blend of essential oils, chitosan or monensin on nutrient intake and digestibility of lactating dairy cows. Anim. Feed Sci. Technol. 214:12-21.

Weinberg, Z. G., G. Ashbell, Y. Hen, and A. Azrieli. 1993. The effect of applying lactic acid bacteria at ensiling on the aerobic stability of silages. J. Appl. Bacteriol. 75:512-518.

Weinberg, Z. G., O. Shatz, Y. Chen, E. Yosef, M. Nikbahat, D. BenGhedalia, and J. Miron. 2007. Effect of lactic acid bacteria inoculants on in vitro digestibility of wheat and corn silages. J. Dairy Sci. 90:4754-4762.

Weiss, W. P., H. R. Conrad, and N. R. St. Pierre. 1992. A theoretically based model for predicting total digestible nutrient values of forages and concentrates. Anim. Feed Sci. Technol. 39:95-110.

Wohlt, J. E. 1989. Use of silage inoculant to improve feeding stability and intake of a corn-silage grain diet. J. Dairy Sci. 72:545-551.

Zhang, J., G. Guo, L. Chen, L. Junfeng, X. Yuan, C. Yu, M. Shimojo, and T. Shao. 2015. Effect of applying lactic acid bacteria and propionic acid on fermentation quality and aerobic stability of oats-common vetch mixed silage on the Tibetan plateau. Anim. Sci. J. 86:595-602. 